\title{
ÚJ TRENDEK ÉS KIHIVÍSOKOK A SZEXUÁLIS ÚTON TERJEDŐ FERTŐZÉSEK TERÜLETÉN
}

\author{
NEW TRENDS AND CHALLENGES IN SEXUALLY \\ TRANSMITTED INFECTIONS
}

\author{
Tisza Tímea \\ bőr-nemigyógyász, a Magyar sTI Társaság alelnöke \\ dr.tisza.timea@boc.hu
}

ÖSSZEFOGLALÁS

A szexuális úton terjedő fertőzések (STI) nemcsak gyakoriságuk miatt, hanem a reproduktív kapacitásra és az életkilátásokra való hatásuk miatt is nagyobb figyelmet érdemelnének. A gonorrhoea kórokozója az Egészségügyi Világszervezet által nyilvántartott multirezisztens szuperbaktériumok magas prioritású listájára került olyan mikrobaként, melynek kezelése hamarosan lehetetlenné válhat. A szifilisz napjainkban reneszánszát éli a kötelező szűrővizsgálatok eltörlése, a társadalmi mobilitás, a szexuális felszabadultság és az orvosok idevonatkozó éberségének lankadása miatt. A méhnyakrákot, szájüregi, végbél- és nemi szervi rákokat, valamint nemi szemölcsöket okozó humán papillomavírus (HPV) a leggyakoribb STI, fontos elörelépés, hogy több mint egy évtizede védőoltással tudunk ellene védekezni. A sokszor tünetmentes nemi szervi klamídiafertőzés szövődményei a meddőségen, a méhen kívüli terhességen keresztül negatív hatást gyakorolnak a népesedésre, ezért szűrővizsgálatokkal kellene gátat vetni a terjedésének. A HIV-fertőzést napjainkban időben felfedezve a HAART (highly active antiretroviral therapy) jóvoltából a nem fertőzöttekével megegyező életminőséget és életkilátásokat biztosíthatunk az érintetteknek, ezért nagyon fontos, hogy a szűrőprogramokkal minél több fertőzöttet megtaláljunk, és kezelésbe vegyünk. Az STI megelőzésében kiemelt szerepet játszik a tájékoztatás, melyet folyamatos kampányokkal kellene biztosítani.

\section{ABSTRACT}

Sexually transmitted infections (STI) are not only frequent but have a major impact on reproductive capacity and life expectancy, therefore they are of great importance. The causative agent of gonorrhea has recently been put on the WHO list of multidrug-resistant superbacteria with high priority as it may soon become untreatable. Syphilis flourishes due to the cancellation of compulsory screening, social mobility, promiscuity, and the slackening of medical awareness. Human papillomavirus (HPV) causing cervical cancer, oral, anal, genital cancers and genital warts, is the most common $\mathrm{STI}$, and it is an important progress that preventive vaccination has become available. Complications of frequently symptom-free genital chlamydiasis, like infertility and extrauterine gravidity, have a major impact on population growth, therefore this infection should 
be stopped by screening programs. HIV infection, if diagnosed at an early stage, can be properly managed by HAART (highly active antiretroviral therapy), and life quality and expectancy similar to those not infected may be guaranteed for the infected, this is why screening programs are of great importance to find and treat those affected. Patient education is a must in the prevention of the STI, therefore continuous campaigns should be performed to achieve this goal.

Kulcsszavak: STD, STI, szexuális úton terjedő fertőzések, gonorrhoea, szifilisz, HIV, AIDS, HPV, klamídia

Keywords: STD, STI, sexually transmitted infections, gonorrhoea, syphilis, HIV, AIDS, HPV, Chlamydia

\section{STI - ELŐFORDUL A LEGJOBB CSALÁDBAN IS}

A WHO adatai szerint világszerte naponta több mint egymillió személyt érintenek a szexuális úton terjedő fertőzések (STI). A négy klasszikus STI - gonorrhea, klamídiázis, szifilisz, trichomoniázis - évente összesen 357 millió új áldozatot szed. Becslések szerint több mint 500 millióan szenvednek nemi szervi herpeszben, és több mint 290 millió nő fertőzött humán papillomavírussal (HPV).

Több mint harminc különféle baktérium, vírus, parazita terjedhet szexuális kontaktus révén. Közülük nyolc kiemelt kórokozó fordul elő a legnagyobb gyakorisággal. Ebből négy betegség, a szifilisz, a gonorrhoea, a klamídiázis és a trichomoniasis gyógyítható jelenleg. A másik négy, vírusos infekció, a hepatitisz B, a herpesz szimplex vírus fertőzés, a HIV- (Human Immunodeficiency Virus, emberi immunhiány vírus) fertőzés és a HPV-fertőzés nem gyógyítható, csupán kezelhetö.

Az STI szexuális érintkezéssel terjed, vagyis hüvelyi, orális és anális szexuális aktusok révén. Egyes STI-k más úton is átadódhatnak, például vér, vérkészítmények révén. Számos STI - köztük a klamídiázis, gonorrhoea, hepatitisz B, HIV, nemi herpesz és a szifilisz - anyáról gyermekére is terjed a terhesség, a szülés, illetve a szoptatás kapcsán.

Az STI-ben szenvedő fertőzöttek jó részének nincsenek tünetei. Ezért változott meg néhány éve ezen betegségcsoport elnevezése STD-ről (sexually transmitted diseases, szexuális úton terjedő betegségek) STI-re (sexually transmitted infections, szexuális úton terjedő fertőzések).

A Centers for Disease Control and Prevention (CDC) adatai szerint huszonöt éves korára minden második ember valamilyen szexuális úton terjedö kórokozóval fertőzötté válik. Az STI fele a szexuálisan leginkább aktív tizenöt-huszonnégy éves korosztályban fordul elő az Egyesült Államokban, és világszerte ebben a korosztályban történik az új HIV-fertőzések 40\%-a is. 
Az európai és a hazai járványügyi helyzet sem kedvezőbb, legfeljebb a bejelentési rendszer nem eléggé jó hatásfokú müködése miatt sokkal kevesebb adat áll rendelkezésünkre a helyzet reális megítélésére. A létező statisztikákból kiolvasható trendek azonban rámutatnak, hogy a nemi úton terjedő fertözések problémája napjaink egyik égető közegészségügyi kérdése lehet. A vészharangot ez ügyben egyelöre csupán a nemigyógyászok kongatják, pedig ezen betegségek szövődményei - a kismedencei gyulladás, a meddőség, a méhen kívüli terhesség, a koraszülés, a perinatális fertőzések, az ízületi gyulladás, a méhnyakrák és egyéb humán papillomavírus- (HPV) asszociált rosszindulatú daganatok stb. számos szakterület orvosainak jelentenek kihívást, így az egészségügyre és a társadalomra rótt terheik, és következményeik nem csekélyek.

Ezért is lenne fontos a prevenció bizonyos elemeire a jelenleginél sokkal nagyobb hangsúlyt fektetni. Míg az oltással megelözhető STI-k területén nincsen okunk szégyenkezni, hiszen 1999 óta a hepatitisz B elleni oltás, 2014 óta pedig a humán papillomavírus elleni vakcina hazánkban ingyenesen hozzáférhető a tizenhárom éves korosztály számára (utóbbi egyelőre csak a lányoknak), a felvilágosítás és a szürőprogramok tekintetében jelentősen lemaradtunk a fejlett országok ilyesfajta aktivitásaihoz viszonyítva.

Pedig napjaink szexuális forradalma hazánkban is ugyanolyan intenzitással zajlik, mint a tengerentúlon, hiszen az internet révén naprakészen jutnak tudomásunkra az idevonatkozó lehetőségek, a szexuális és pornográf tartalmak. A randiappok (például Tinder) lehetővé teszik a gyors szexpartnerkeresést, de a szabályozás miatt némileg visszaszorult utcai prostitúció helyébe lépő szexuális szolgáltatást hirdető internetes oldalak, a swinger klubok, a „masszázsszalonok”, „szaunák”, kínálata révén továbbra is számtalan lehetőség adódik a vágyak kielégítésére. Ami a leginkább veszélyeztetettnek tekinthető fiatalok szexuális egészségről (akár a nem kívánt terhesség, akár az STI vonatkozásában) való ismereteit illeti, a korosztályos STI statisztikai adatok és hazánkban sajnálatosan kisszámú, sporadikusan végzett felmérések mutatják, hogy baj van, és bőven lenne teendő. Még messzebb vezet, ha azokra a jelenségekre keressük a magyarázatot, amikor egyes kamasz lányok pornószínésznőket tartanak példaképüknek, illetve, hogy a tinédzserek között a szex sok esetben már nem a két ember közti intimitás legmagasabb fokú megnyilvánulása, hanem egyfajta szórakozási forma.

Mielőtt azonban az STD-kérdést egyfajta generációs problémává degradálnánk, látnunk kell azt is, hogy az érintettek másik fele a huszonöt év feletti korosztályokból kerül ki, és olyan jelenségek is felütik a fejüket, mint például, hogy a merevedési zavar kezelésére kifejlesztett gyógyszerek afféle mellékhatásaképp napjainkban az idősebb korosztályban is egyre többen akvirálnak STI-t.

Megemlíthetjük még a sugar baby-sugar daddy jelenséget, amikor egy idősebb úr egy fiatal hölgyet támogat anyagilag, szexuális ellenszolgáltatás fejében, illetve a szexturizmust, ami a sztereotípiákkal szemben nem csupán az urak kivált- 
sága. Jól szituált európai, észak-amerikai és ausztrál középkorú hölgyek ugyanis, romantikus kalandok reményében, nem ritkán ellátogatnak Afrika, Ázsia vagy Dél-Amerika efféle szolgáltatásokra szakosodott turistaparadicsomaiba. Mint látjuk tehát, napjainkban számtalan lehetőség adódik alkalmi szexuális kapcsolatok lebonyolítására, és a kellő prevenciós ismeretek hiányában STI akvirálására. Kijelenthetjük, hogy aki szexuális életet él, leszámítva a kölcsönösen monogám, tartós párkapcsolatban élöket, ki van téve az effajta veszélyeknek.

\section{GONORRHOEA (TRIPPER, KANKÓ) - EGY „SZUUPERBAKTÉRIUM” OKOZTA BETEGSÉG}

A gonorrhoea világszerte a második leggyakrabban bejelentett szexuális úton terjedő fertőzés. Kórokozója, a Neisseria gonorrhoeae elsősorban a nemi szerveket fertőzi meg, de előfordulhat a végbél és a száj-garat nyálkahártyáján is, tehát védekezés nélküli orális és anális szex révén is átadható. A kórokozó tünetmentes személyben is jelen lehet, de férfiakban a fertőzés az esetek legnagyobb részében fájdalmas vizeléssel, gennyes folyással járó akut húgycsőgyulladásként jelentkezik. Nőkben ezzel szemben enyhe, jellegtelen tüneteket okoz (alhasi diszkomfort, enyhe folyás, közti vérzés), de hosszú ideig akár tünetmentes is lehet. Az időben fel nem fedezett gonorrhoea mindkét nemben a belső nemi szervekben okozott gyulladás révén súlyos szövődményekhez, szepszishez, meddőséghez vezethet.

A gonorrhoeát kezdetben penicillinnel gyorsan és hatékonyan lehetett kezelni, de néhány éven belül már előfordultak penicillinre nem reagáló esetek, így hamarosan a spectinomycint és a tetraciklint is fel kellett venni a terápiás fegyvertárba. Az 1980-as évek közepére azonban olyan gyakorivá váltak a penicillin-, valamint a tetraciklin-rezisztens törzsek, hogy újabb antibiotikumokat kellett bevetnünk. Az új terápiás előírások a ceftriaxont, a cefiximet, az azithromycint és a fluorokinolonokat javasolták a gonorrhoea kezelésére, de már az 1980-as évek elején megjelentek a kinolonrezisztens, a 90-es évek elején a cefiximrezisztens, a 90-es évek végén pedig az azithromycin-rezisztens esetek, melyeket jellemzően eleinte Európán kívüli területekről jelentettek, ám gyorsan elterjedtek az USA-ban és Európában is.

2009-ben Japánban izoláltak először ceftriaxonra rezisztens N. gonorrhoeae törzset (H 041m, avagy Kiotó-törzs), ezért 2012 óta a ceftriaxont már csak azithromycinnel kombinálva ajánlják a gonorrhoea kezelésére az európai és USA-beli guideline-ok.

2018-ban azonban az Egyesült Királyságban egy olyan gonorrhoeás pácienst találtak, aki mindkét ajánlott antibiotikumra rezisztens baktériumtörzzsel fertözödött, és gyakorlatilag egyetlen egyéb, szokványos antibiotikumra sem reagált, komoly fejtörés elé állítva ezzel az őt kezelő orvosokat. A N. gonorrhoeae baktérium tehát felkerült arra a listára, melyen az emberiségre leginkább veszélyes multirezisztens szuperbaktériumok szerepelnek. 
A WHO 1990 óta egy antimikrobiális rezisztencia surveillance program (Gonococcal Antimicrobial Surveillance Programme, GASP) keretében követi nyomon a N. gonorrhoeae antibiotikum érzékenységének alakulását, melynek munkájába az Euro-GASP-on keresztül Magyarország is bekapcsolódott. Az Euro-GASP az ECDC (European Centre for Disease Prevention and Control) európai uniós szervezet keretein belül müködteti a surveillance rendszert.

Az ECDC ezen túlmenően regisztrálja a tagországok járványügyi adatait is, így egyre pontosabb képet kaphatunk a szexuális úton terjedő fertőzések gyakoriságáról Európában. 2016-ban például 75349 gonorrhoeás esetet jelentettek huszonnégy európai országból, és az is világosan tetten érhető, hogy a gonorrhoeás esetek száma 2010-2016 között mindkét nemben megduplázódott. A betegség nemenkénti megoszlása - 80-20\% a férfiak javára - tükrözi egyrészt az MSM(men who have sex with men, homoszexuális férfiak) populáció nagyobb arányát, valamint valószínüleg részben betudható a női fertőzések gyakori tünetmentességének is. A női gonorrhoea ugyanis sokszor csak az indexbeteg kontaktusainak felderítése révén derül ki, azonban mivel az utóbbi néhány évben hazánkban ezt már nem kötelező a kezelőorvosnak elmondani, a beteg belátására van bízva, hogy felfedi-e a fertőzés forrását, lehetővé téve annak kezelését és a fertőzési láncolat megszakítását.

Az $N$. gonorrhoeae antibiotikum-rezisztencia helyzet súlyosságát jelzi, hogy a WHO antibiotikum-rezisztens baktériumok kezelésére irányuló kutatás-fejlesztési globális prioritási listáján a gonorrhoea kórokozója már 2017-ben a magas prioritású kategóriába került. Jelenleg fejlesztés és kipróbálás alatt áll néhány új antibiotikum, úgymint a solithromycin, a gepotidacin, illetve a zoliflodacin, melyek önmagukban vagy ceftriaxonnal együtt adva megoldást jelenthetnek a multidrug-rezisztens gonorrhoea problémájára.

\section{SZIFILISZ (LUESZ, VÉRBAJ) - „A NAGYSZERŨ IMITÁTOR, A BETEGSÉGEK MAJMA”}

Az Európába való behurcolását és igen gyors elterjedését követő csaknem ötszáz év során kezelhetetlen, halálos kórként rettegett, majd a penicillinkezelés bevezetésével jelentősen megszelídült szifilisz tünettana rendkívül színes, ezért is kapta a „nagyszerű imitátor” jelzőt. A korai szak primer affekciójával (kemény sánkerével) a bőr-nemigyógyászokon kívül - akik rendszerint felismerik -, a kórokozó behatolási helyének függvényében (a nemi szerveken, a végbélnyílásban, a szájban) nőgyógyászok, urológusok, proktológusok, fül-orr-gégészek, fogorvosok találkozhatnak, akik viszont manapság csak a legritkább esetben gondolnak erre a lehetőségre. A szexuális anamnézis precíz felvétele ugyanis kizárólag a venerológusok kikérdezési rutinjának része, így ha a páciens magától nem számol be arról, hogy prostituálttal bonyolított védekezés nélküli 
aktust, netán egyéb egyéjszakás kalandja akadt alig vagy egyáltalán nem ismert partnerrel, vagy a masszázsszalonban óvszer nélküli orális aktussal záródott a „kezelés”, akkor könnyen félrediagnosztizálás és félrekezelés lehet az információhiány következménye. A primer affekció egyébként is spontán elmúlik néhány hét alatt, így a beteg abba a tévhitbe ringathatja magát, hogy meggyógyult. Hat héttel később azonban jelentkeznek a másodlagos szakasz változatos bőrtünetei, esetleg általános tünetekkel (láz, fejfájás, nyirokcsomó megnagyobbodás, máj-lépduzzanat, végtagfájdalmak stb.) kísérve, melyek többféle kiütéses fertőző betegségre vagy más bőrbetegségekre hajazhatnak. Ha ilyenkor végre bőr-nemigyógyászaton szakszerü ellátásra kerül a beteg, akkor a gyógyulás gyors és tökéletes, azonban ha ez továbbra sem sikerül, akkor egy sok éven át húzódó, egyre kevésbé tipikus bőrtünetekkel, illetve hosszabb tünetmentes szakaszokkal jellemezhető időszak következik, ami közben a beteg fertőz. Kb. tíz év múlva megjelennek a belszervi szifilisz tünetei, ahol sokféle belgyógyászati (elsősorban kardiovaszkuláris), neurológiai, pszichiátriai, szemészeti, fül-orr gégészeti, ízületi betegség képében találkozhatnak vele a különféle szakterületek orvosai. Mivel a szifilisz nemcsak a laikusok, hanem az orvosok többségének tudatában is afféle historikus betegségként él, sajnos a kollégák igen ritkán gondolnak erre a lehetőségre, és amióta megszüntették azt a régi gyakorlatot, hogy minden kórházba kerülö betegnél automatikusan megtörténik a luesz szerológiai vizsgálat (Wassermann-teszt és más szürővizsgálatok), egyre gyakrabban fordul elö, hogy ezek a betegek helytelen diagnózisokkal és inadekvát kezelésekkel tévelyegnek hosszasan az egészségügy útvesztőiben.

A konnatális (veleszületett) szifilisz előfordulási gyakorisága egy ország fontos közegészségügyi mutatója. Hazánkban 1997 óta sajnálatos módon csaknem minden évben regisztrálnak néhány ilyen esetet. A várandós gondozás részeként az első trimeszterben végzett szifilisz szerológiai vizsgálat csak részben hatékony prevenciós lehetőség, hiszen a terhesség folyamán a későbbiekben is bekövetkezhet a megfertőződés. Még inkább veszélyeztetettek azok a gravidák, akik egyáltalán nem vesznek részt terhesgondozáson, és ilyenkor sok esetben csak a szüléskor derül fény az anya és a magzat/újszülött lueszes fertőzésére.

A szifilisz akvirálásának rizikója természetesen szorosan összefügg a szexuális magatartással, így a promiszkuáló MSM, a prostituáltak és azok kliensei, az intravénás kábítószert használók körében a legmagasabb a betegség gyakorisága, de többszörös áttétel révén előfordulhat olyan társadalmi csoportokban is, melyek tagjai egyetlen rizikócsoportba sem tartoznak. Kitörhetnek időnként kisebb lokális járványok, amilyen például 2018-ban a szomszédságunkban, a szlovákiai Tőketerebesen zajlott, és itt a fertőzés terjedésében szerepet kapott a zsúfoltságból, alacsony higiénés színvonalból, az elemi egészségügyi ismeretek hiányából adódó aszexuális terjedés is. Az efféle aszexuális terjedés egyébként 
a szabályt erősítő kivétel, hiszen a szifilisz túlnyomóan szexuális aktus, továbbá vérátömlesztés, intravénás kábítószer-használat, nem fertőtlenített tetováló eszközök révén, valamint fertőzött anyáról gyermekére terjed a terhesség, a szülés, illetve a szoptatás időszakában.

Ami a szifilisz hazai járványügyi helyzetét illeti, a második világháborút követően hazánkban a szifiliszes (és a gonorrhoeás) megbetegedések száma igen magas volt, ezért 1952-ben megalapították az Országos Bőr-Nemikórtani Intézetet (OBNI), mely 2005-ben bekövetkezett megszüntetéséig a szervezett antivenereás küzdelem stratégiai és operatív központjaként kiemelkedő hatékonysággal müködött. Első feladata a korai fertőző szifilisz felszámolása volt, amit szürővizsgálatok, kötelező fertőzőforrás-kutatás, a betegek és kontaktusaik számára biztosított ingyenes kezelés, gondozás, kötelező anonim adatszolgáltatás révén 1960-ra gyakorlatilag sikerült megvalósítania. A 122 bőr-nemibeteg-gondozóból álló hálózat szakorvosai a törvényi szabályozás és az OBNI mindenkori szakmai irányelvei alapján végzett munkája csakhamar látványos eredményeket produkált, így az 50 -es évek végére a szifiliszes esetek száma száz alá esett, míg 1960-ban mindössze két új, fertőző szifiliszben szenvedő beteget észleltek. 1960-1980 között a világtrendeknek megfelelően Magyarországon is jellemző szexuálismagatartás-változás miatt átmeneti emelkedés következett be, majd a 90-es évek elejére ismét csökkenést észleltek, vélhetöleg az AIDS megjelenése kiváltotta félelemnek köszönhetően. Ez azonban csak ideig-óráig tudott gátat szabni a vérbaj terjedésének, mert az ezt követő években ismét emelkedett az esetszám, egy 1997-es drámai csúccsal (az előző évhez képest 40\%-os növekedés). Ugyanekkor az addig jellemző fövárosi dominancia is megszünt, a vidéki esetszámok meghaladták a budapestit a migráció és a prostitúció következményeképpen. A gonorrhoeához hasonlóan a férfiak dominanciája mindvégig megfigyelhetö, ami szintén az MSM körében észlelhető magasabb előfordulási gyakoriságnak tudható be. A következő tizenöt évben további emelkedést tapasztalhattunk, ami a határok rendszerváltást követő megnyitásával, a nagyobb társadalmi mobilitással, a tranzitforgalommal és a szexuális szabadosság növekedésével magyarázható. Az utóbbi hét évben az európai trendeknek megfelelően a szifiliszes morbiditás hazánkban is jelentősen növekszik. Az ECDC adatai szerint például míg Európában 2011-ben 20 500, 2015-ben már 28701 szifiliszes eset fordult elö, és ez a tendencia egyre kifejezettebbé válik. Hazánkban 2015-ben 617, 2016-ban 714, 2017-ben 712, míg 2018-ban 671 szifiliszes megbetegedést regisztráltak. Ezek a számok persze messze alulmúlják a szomszédos Ukrajnában vagy a szovjet utódállamok némelyikében (Belarusz, Moldávia) évek óta tomboló szifiliszjárvány epidemiológiai mutatóit, mégis jól illusztrálják azt, ami a nemibeteg-ellátás 50 -es években kialakított és szigorú következetességgel alkalmazott, törvények által szabályozott rendszerének széthullása után történik Magyarországon. 


\section{HUMÁN PAPILLOMAVÍRUS FERTŐZÉS - A LEGGYAKORIBB SZEXUÁLIS ÚTON TERJEDŐ FERTŐZÉS, EGY INFEKCIÓ, MELY RÁKOT OKOZHAT, ÉS VÉDŐOLTÁSSAL MEGELŐZHETŐ}

2008-ban Harald zur Hausen német virológust egy olyan felismerésért jutalmazták orvosi Nobel-díjjal, melyet több mint harminc évvel azelött tett, nevezetesen, hogy a méhnyakrák okozója a humán papillomavírus (HPV). Ekkor már csaknem két éve a piacon voltak a HPV-fertőzést megelöző négy-, illetve kétkomponensü vakcinák. Mindkét oltóanyag alkalmasnak bizonyult a HPV két leggyakoribb onkogén típusával, a 16-os és a 18-as típussal való megfertőződés megakadályozására, melyek a méhnyakrákos esetek mintegy $70 \%$-áért felelősek. Fél éve látott napvilágot az a brit tanulmány, mely szerint Skóciában a bivalens HPV-vakcináció következtében 90\%-kal csökkent a méhnyakrák-megelöző elváltozások gyakorisága, tehát láthatjuk, hogy a HPV-védőoltás már néhány év távlatában is látványos eredményeket produkál a méhnyakrák megelőzésében.

A négykomponensủ védőoltás emellett, mintegy „bónuszként”, a nemi szervi szemölcsök 90\%-át okozó 6-os és 11-es típusokkal szembeni védelmet is biztosította. Ez a hozzáadott érték nem elhanyagolható annak fényében, hogy minden tizedik ember élete során nemi szervi szemölcsökben szenved, melyek kezelése hosszadalmas, költséges és nem ritkán fájdalmas is. A kvadrivalens HPV-védőoltás idevonatkozó hatékonyságát bizonyítja az Ausztrál Nemzeti Vakcinációs Program sikere, melynek hatására $80 \%$-os átoltottság mellett négy év alatt $92,6 \%$-os csökkenést figyeltek meg a nemi szervi szemölcsök elöfordulásában a huszonegy év alatti nőkben, és a kedvező hatás a heteroszexuális férfiakra is jelentős mértékben kihatott a nyájimmunitás révén.

Még további előnyöket biztosít a 2016 óta elérhető kilenckomponensü HPV-védőoltás, mely a hét leggyakoribb onkogén típus ellen védelmet biztosítva a méhnyakrákos esetek 90\%-át képes megelőzni, a már ismert, nemi szervi szemölcsökkel szembeni 90\%-os protektív hatás mellett. 2018 őszétől már ezt a vakcinát kapják meg Magyarországon a 7. osztályos lányok, és tervezik a fiúk oltásának elindítását is.

A HPV-fertőzés a leggyakoribb szexuális úton terjedő infekció: az emberek 80\%-a élete során valamikor átesik rajta. A többség tünetmentesen hordozza, míg másokban különféle jó- vagy rosszindulatú bőr-, illetve nyálkahártya növedékek alakulnak ki.

A HPV okozza a rákos esetek 5\%-át világszerte, és itt nem csupán a méhnyakrákra, de egyéb nemi szervi laphámkarcinómákra, a végbélrákra, és a legutóbbi kutatások eredményei szerint a fej-nyaki rákok jó részére is gondolni kell.

A fej-nyaki regió HPV-asszociált laphámrákos eseteinek száma Európában és az USA-ban az utóbbi harminc évben megháromszorozódott, és az esetek több mint 90\%-ában a HPV 16-os típusa szerepel oki tényezőként. Ami a hazai helyzetet illeti, az Országos Onkológiai Intézet 2013-2015 között diagnosztizált 153 
szájgarati laphámrákos betege közül minden ötödik esetben volt HPV-eredetű a daganat.

Ez a betegség egyébként férfiakban háromszor gyakrabban fordul elö, mint nökben, és hatvanéves kor körül jelentkezik leggyakrabban. Mivel - szemben például a méhnyakrákkal - a szájüregi laphámkarcinómák esetében nem észlelhető rákmegelőző állapot, nagyon nehéz korai állapotban kiszürni, így a betegek általában már manifeszt tünetekkel, sőt, regionális nyirokcsomóáttétekkel kerülnek kezelésre. A HPV-asszociált szájüregi laphámrákok prognózisa ugyanakkor jelentősen kedvezőbb, mint az egyéb okból kialakuló szájüregi rákoké, mivel sokkal jobban reagálnak az alkalmazott kemo- és radioterápiára.

Ami a méhnyakrákot illeti, ez a második leggyakoribb női daganatos megbetegedés, mely évente mintegy félmillió nőt érint világszerte. Hazánkban 1200 nő betegszik meg évente méhnyakrákban, akiknek mintegy fele bele is hal a betegségébe, ami azt jelenti, hogy ezek a betegek túlzottan későn kerültek ellátásra. Ez aláhúzza a megelőzés, azaz a korai felismerést célzó szürővizsgálatok és a HPV-vakcináció fontosságát. 2003-ban indult el az Országos Tisztiföorvosi Hivatal meghívásos alapon történő méhnyakrák-szürési programja a WHO által elfogadott módszer szerint 25-65 éves korú nők számára háromévente, sejtkenet alapú vizsgálattal. Mivel az átszürtség nem növekedett kielégítő mértékben, 2013-tól új programot indítottak a szürés alapellátási szinten való megvalósítására védönők bevonásával, ami a kistelepülésen élő nők számára jelenthet előrelépést a méhnyakrák-prevencióban.

\section{KLAMÍDIÁZIS - A LEGGYAKORIBB BAKTERIÁLIS STI, A „CSENDES GYILKOS"}

A klamídiázis a Chlamydia trachomatis nevủ baktérium által okozott, szexuális úton terjedő fertőző betegség. A gonorrhoeához hasonlóan hüvelyi, orális és anális szex révén egyaránt átadható, illetve hüvelyi szülés közben a fertőzött anya az újszülöttet is megfertőzheti.

A klamídia nőkben a méhnyakcsatorna gyulladását, mindkét nemben húgycsőgyulladást és proktitiszt (végbél nyálkahártya-gyulladást) okozhat. A nők fertőzése kismedencei gyulladáshoz, majd a méhkürtök elzáródása miatt méhen kívüli terhességhez, meddőséghez, krónikus kismedencei fájdalomhoz vezethet. A férfiakban mellékhere gyulladás, mindkét nemben ízületi gyulladás (sexually acquired reactive arthritis, SARA) alakulhat ki.

A klamídiázisra jellemző, hogy sokáig tünetszegény vagy akár teljesen tünetmentes is lehet a megfertőződött személy, aki közben tudtán kívül másokat is megfertőzhet. Talán még ennél is nagyobb baj, hogy az alattomos kórokozó közben egyre beljebb hatol a nemi szervek nyálkahártyáján, és sokszor csak akkor derül ki a krónikus fertőzöttség ténye, amikor már valamilyen szövődmény kiala- 
kult. Éppen ezért a világban sok helyen (például Svédország, Egyesült Államok, Kanada, Anglia) szervezett szürőprogramokkal igyekeznek elejét venni a fertőzés terjedésének és a súlyos következményeknek. A klamídiafertőzés ugyanis időben felfedezve antibiotikummal tökéletesen gyógyítható, míg a szövődmények ellátása lényegesen kevesebb sikerrel kecsegtet. Mivel a klamídiafertőzés a 15-24 éves korosztályban a leggyakoribb, melyben gyakorisága akár a 10\%-ot is elérheti, valamint tekintve, hogy a női reproduktív kapacitás károsodása a legkritikusabb klamídia okozta probléma, ezért ezen szürések elsődleges célpontjai többnyire a huszonnégy éves és ennél fiatalabb szexuálisan aktív nők. A perinatális fertőzések megelőzésére néhány országban a terheseket is szürik.

Európában országonként többféle klamídiaszürési és ellátási protokollal találkozunk, Magyarországon például a fertőzéssel diagnosztizált betegek szexuális partnereit tesztelik és részesítik kezelésben.

A limfogranulóma venereum (LGV) szintén klamídia okozta betegség (a baktérium más szerocsoportjai szerepelnek itt kórokozóként), melyet a legutóbbi időkig trópusi nemi betegségként tartottak számon. Néhány éve azonban időről időre Nyugat-Európában, az Egyesült Államokban és Ausztráliában kisebb helyi proktitiszjárványokat okoz MSM-csoportokban. Az első ilyen járvány 2003-ban Rotterdamban tört ki, és tizenöt férfit érintett. 2016-ban az ECDC adatai szerint már 2043 ilyen esetet regisztráltak, melyek 86\%-a Franciaországban, Hollandiában és az Egyesült Királyságban fordult elő. Az ismert HIV-státusú LGV-s betegek 78\%-a HIV-fertőzöttnek is bizonyult. Magyarországon az első esetet 2012-ben diagnosztizálták a nyíregyházi bőr- és nemibeteg-gondozóban, 2018-ban már 33 LGV-esetet észleltek hazánkban.

Az LGV-proktitisz tünetei gyulladásos bélbetegségre emlékeztetnek: a végbélből nyákos-véres váladék ürül, láz, hasi görcsök, székrekedés jellemzi. Súlyosabb esetekben, és ha nem kezelik időben, krónikus sipolyok és szükület alakulhat ki. A tünetek jellege miatt a betegek legtöbbször a proktológián, gasztroenterológián jelentkeznek, ahol ma még igen ritkán gondolnak arra, hogy egy nemi betegség is állhat a háttérben, így a kórisme felállítása sokszor késedelmes. Előfordulnak tünetmentes hordozók is, akik a fertőzés terjesztésében kulcsszerepet játszanak. A veszélyeztetett csoportokban végzendő szürővizsgálatok komoly szerepet játszanának a probléma megfékezésében.

\section{HIV-FERTŐZÉS, AIDS - GYÓGYÍTHATATLAN, DE KEZELHETŐ}

Az 1980-as évek elején, a HIV-járvány kezdetén mindenki úgy vélekedett, hogy az AIDS (Acquired Immune Deficiency Syndrome, szerzett immunhiányos tünetegyüttes) javarészt a homoszexuálisok betegsége, annak ellenére, hogy hamarosan kiderült, hogy a fertőzés vér- és vérkészítmények, valamint intravénás 
kábítószerezés révén közös tü- és fecskendőhasználat útján is terjed, továbbá a heteroszexuális együttlét során is átadható. Akkoriban erősen tartotta magát az a hiedelem, hogy a HIV-fertőzés és az AIDS problémája - leszámítva a „saját hibájukon kívül" megfertőződött hemofíliásokat, és más betegeket, akik vérátömlesztés vagy egyéb egészségügyi beavatkozások közben fertőződtek meg - kizárólag speciális társadalmi csoportokat érint: a homo- és biszexuális férfiakat, az intravénás kábítószer-használókat, a prostituáltakat és ezek szexuális partnereit. A HIV-fertőzéshez tehát a kezdetektől erősen kapcsolódott egyfajta stigmatizáció, amit a ma divatos kifejezéssel akár áldozathibáztatásnak is nevezhetnénk. Paradox módon hazánkban az első HIV-fertőzéssel diagnosztizált páciens egy hemofíliában szenvedő gyermek volt 1985-ben (1986. július 1. óta történik Magyarországon HIV-szürés a véradáskor), az első AIDS-es beteg pedig egy monogám, heteroszexuális férfi, aki szívmütétje során akvirálta a fertőzést.

A HIV-fertőzés napjainkban is az egyik legfenyegetőbb közegészségügyi probléma a világban: a járvány kezdete óta kb. 77,3 millióan fertőződtek meg a HIV-vel, és 35,4 millióan haltak meg AIDS-szel összefüggő betegségekben. A HIV-fertőzöttek túlnyomó többsége az alacsony és a közepes jövedelmű országokban él, kb. kétharmaduk Afrika Szaharától délre eső részén.

A UNAIDS (Joint United Nations Programme on HIV/AIDS, Közös ENSZ HIV/AIDS Program) ,90-90-90" prevenciós és terápiás programja, mely szerint 2020-ra a HIV-fertőzöttek 90\%-a tisztában lesz HIV-státusával, ezek 90\%-a antiretroviralis kezelésben részesül, és a kezelés alatt állók 90\%-a vírusszuppresszió alatt áll (a vérükben molekuláris biológiai eljárással nem mutatható ki HIV-vírus, vagyis nem fertőznek), úgy tünik, nem fog 2020-ra maradéktalanul megvalósulni. A 2017. év végére 75\%, 79\%, illetve 81\%-nál tartott ez a projekt, ezen belül a legkevésbé sikeresnek Nyugat- és Közép-Afrikában, Kelet-Európában és Közép-Ázsiában bizonyult. Míg Afrikában a heteroszexuális terjedés jellemző, Kelet-Európában - a tőlünk nem oly távoli Ukrajnában, Oroszországban, a Baltikumban - a kábítószer használattal összefüggésben észlelhető egy ijesztően gyorsan kibontakozó járvány. Ha megnézzük a UNAIDS 2017-es adatait az újonnan akvirált HIV-fertőzés megoszlásáról az egyes lakossági csoportokban, azt láthatjuk, hogy a friss fertőzések fele napjainkban már korántsem a marginalizált, stigmatizált vagy kriminalizált csoportokban fordul elő, hanem az ún. „,normál” populációban.

Az 1995 óta világszerte, így hazánkban is elérhető HAART (highly active antiretroviral therapy, mely kettő vagy több antiretroviralis gyógyszer kombinációja) jóvoltából a HIV-fertőzés, illetve az AIDS jól kezelhető, krónikus betegséggé vált. A fejlett országokban, ahol ez a terápia elérhetö, aki időben szerez tudomást fertőzöttségéről, hasonló életkilátásokra számíthat, mint az, aki nem fertőződött meg a vírussal. Manapság az így kezelt HIV-fertőzöttek már nem az AIDS-szel összefüggő okok miatt halnak meg. 
Ami a hazai járványügyi helyzetet illeti, a kezdetektől 2018 szeptemberéig öszszesen 3728 HIV-fertőzöttet regisztráltak, 2854 férfit és 367 nőt, míg 516 anonim szürésben jelentkező esetében az illető neme ismeretlen maradt. Ugyanezen időszak alatt 987 AIDS-beteget diagnosztizáltak, közülük 192 heteroszexuális, 692 homo-/biszexuális, 11 intravénás kábítószerező, 20 vérzékeny, 14 transzfúzió által fertőződött, 42 esetében pedig nem volt kideríthető a fertőződés módja.

Hazánkban a HIV-fertőzöttek között a homoszexuális népesség az európai átlaghoz (39\%) képest felülreprezentált, mintegy 65\%-ot tesz ki. Magas kockázatúnak tekinthetőek továbbá az intravénás kábítószer-élvezők, a női és férfi prostituáltak, a magas HIV-prevalenciájú földrajzi területről érkező személyek (menekültek, diákok, turisták, üzletemberek), fentiek szexuális partnerei és mindazok, akik magukat kockázatban lévőnek definiálják. Az ő esetükben a HIV-szürés elvégzése ajánlatos. A hazai intravénás kábítószer-élvezők között, akik többsége egyébként rendszeresen jár szürésre, egyelöre meglepően alacsony a HIV-fertőzöttség, míg mintegy 40\%-uk hepatitis C vírussal fertőzött. A magyarországi szexipari munkások fertőzöttségéről nagyon kevés adat áll rendelkezésre, az ismert HIV-fertőzöttek között arányuk egyelöre alacsonynak mondható.

Mikor kell egy orvosnak arra gyanakodni, hogy páciense tünetei hátterében HIV-fertőzés lehetséges? Bizonyos betegségek, illetve szimptómák észlelésekor minden esetben gondolni kell erre, ilyenek például a tüdő tuberkulózisa, a generalizált nyirokcsomó-megnagyobbodás, az ismeretlen eredetủ demencia, a krónikus, ismeretlen eredetủ láz, hasmenés, kandidiázis, a generalizált herpesz szimplex fertőzés, illetve a jellegzetes AIDS-asszociált tumorok, mint a Kaposi-szarkóma és non-Hodgkin-limfóma. Ezen állapotok észlelésekor a diagnosztikus HIV-teszt elvégzése feltétlenül javasolt. Ugyanígy, ha rizikócsoportba tartozó betegben az akut HIV-fertőzés tüneteire emlékeztető tünetegyüttest tapasztalunk - láz, torokgyulladás, hasmenés, izom-ízületi fájdalom, generalizált nyirokcsomó-megnagyobbodás, fejfájás -, szintén indokolt a HIV-teszt elvégzése.

Hazánkban az egészségügyi dolgozók tủvel történő sérüléssel kapcsolatos HIV fertőződése rendkívül ritka, de ha ismert HIV-fertőzött beteghez kapcsolódóan történik ilyen baleset, a négy órán belül megkezdett PEP (posztexpozíciós profilaxis) biztonsággal kivédi a fertőződést. Ez a terápia a fővárosi Szent László Kórház HIV-ambulanciáján érhető el.

A HIV-prevencióban - mint minden STD esetében - elsődleges fontosságú a kondom használata, de aki HIV-fertőzöttel él rendszeresen szexuális életet (annak ellenére, hogy az adekvátan kezelt fertőzöttek vérében a vírus kópiaszám praktikusan zéró), vagy nem hajlandó óvszert használni, egy HIV-ellenes gyógyszerkombináció folyamatos szedésével minimálisra csökkentheti a megfertőződés kockázatát. 2014 májusa óta ajánlott a WHO által az ún. PrEP- (preexpozíciós profiaxis) kezelés, mely a fejlett világ magasabb HIV-prevalenciájú országaiban sok helyütt díjmentesen vagy támogatottan hozzáférhető a magas kockázatnak ki- 
tett személyek számára. Hazánkban ez a lehetőség a fővárosi Szent László Kórház HIV-ambulanciáján, illetve a vidéki decentrumokban, Debrecenben, Miskolcon és Pécsen elérhető, de a gyógyszert a társadalombiztosító egyelöre nem támogatja.

Az újonnan felismert HIV-fertőzöttek száma hazánkban 2006 és 2015 között megnégyszereződött, ami részben a fertőzés terjedésének tudható be, de másfelöl talán a folyamatos (bár még mindig az optimálistól túlzottan messze lévő mértékü) betegedukációnak is szerepe lehet ebben. A felvilágosító kampányokban többek között a szürést is igyekeznek minél szélesebb körben népszerüsíteni, hiszen a kiszürt fertőzöttek a HAART mellett ma már teljes életet élhetnek, és nem fertőznek tovább. A prevencióban olyannyira fontos betegedukáció ma hazánkban szinte kizárólag civil kezdeményezések formájában valósul meg, a Nemzeti Népegészségügyi Programban ugyanis sajnálatos módon semmilyen HIV- vagy STI-prevencióra irányuló tevékenység nem szerepel. Ez különösen annak fényében elszomorító, hogy a friss HIV-fertőzöttek között egyre több a fiatal, tizennyolc év alatti páciens.

\section{IRODALOM}

Ali, H. - Guy, R. J. - Wand, H. et al. (2013): Decline in In-patient Treatments of Genital Warts among Young Australians Following the National HPV Vaccination Program. BMC Infectious Diseases, 13, 140 DOI: 10.1186/1471-2334-13-140, https://bmcinfectdis.biomedcentral.com/articles/10.1186/1471-2334-13-140

ANTSZ (2018): Tájékoztató a 2018/2019. évi HPV elleni iskolai kampányoltásról. https://www. antsz.hu/felso_menu/temaink/jarvany/hpv_2018/hpv_tajekoztato_2018.html

Balla E. - Petrovay F. - Balázs A. et al. (2015): Confirmed Cases of Lymphogranuloma Venereum in Hungary, 2012 to 2014: Supportive Diagnostic Tool of Immunoblotting. Sexually Transmitted Infections, 91, 3, 200. DOI: 10.1136/sextrans-2014-051673, https://sti.bmj.com/content/ 91/3/200.long

Berecz M. - Horváth A. (2001): A syphilis epidemiológiai trendjei Magyarországon. Venereológia, III, 4, http://hippocrateslap.hu/uploads/ujsag/2001-4/a-syphillis-epidemiologiai-trendjei-magyarorszagon.pdf

ECDC (2018): Lymphogranuloma venereum. Annual Epidemiological Report for 2016. SURVEILLANCE REPORT. https://ecdc.europa.eu/sites/portal/files/documents/AER_for_2016-lymphogranuloma-venereum.pdf

European Centre for Disease Prevention and Control (2019): Gonorrhoea-Annual Epidemiological Report for 2017. https://ecdc.europa.eu/en/publications-data/gonorrhoea-annual-epidemiological-report-2017

Gillison, M. L. - Koch, W. M. - Capone, R. B. et al. (2000): Evidence for a Causal Association between Human Papillomavirus and a Subset of Head and Neck Cancers. Journal of the National Cancer Institute, 92, 9, 709-720. DOI: 10.1093/jnci/92.9.709, https://academic.oup.com/ jnci/article/92/9/709/2906131

Karlovsky, M. - Lebed, B. - Mydlo, J. H. (2004): Increasing Incidence and Importance of HIV/ AIDS and Gonorrhea among Men Aged $\geq 50$ Years in the US in the Era of Erectile Dysfunction Therapy. Scandinavian Journal of Urology and Nephrology, 38, 247-252. DOI: 10.1080/00365590410025488, https://bit.ly/2ukLI5K 
Koiss R. - Boncz I. - Hernádi Z. et al. (2017): Javaslat a hazai méhnyakszürési eljárásrend korszerüsítésére. Orvosi Hetilap, 158, 52, 2062-2067. http://real.mtak.hu/71928/1/650.2017.30896.pdf

Low, N. - Bender, N. - Nartey, L. et al. (2009): Effectiveness of Chlamydia Screening: Systematic Review. National Journal of Epidemiology, 38, 2, April, 435-448. DOI: 10.1093/ije/dyn222, https://academic.oup.com/ije/article/38/2/435/654660

Palmer, T. - Wallace, L. - Pollock, K. G. et al. (2019): Prevalence of Cervical Disease at Age 20 after Immunisation with Bivalent HPV Vaccine at Age 12-13 in Scotland: Retrospective Population Study. The BMJ, 365, DOI:10.1136/bmj.11161, https://www.bmj.com/content/365/bmj.11161

Szlávik J. (2017): A HIV-fertözés pre- és posztexpoziciós profilaxisa. https://www.imeonline.hu/ conference/176/sti 2017 ertesito.pdf

Szlávik J. (2018): Korszerü HIVIAIDS terápia 2018. Magyar STI Társaság XXIII. Nagygyülése

Tabák R. - Tabák Á. - Várkonyi V. (2010): Connatalis syphilis. Orvosi Hetilap, 151, 2, 54-61. DOI: 10.1556/OH.2010.28783, https://akademiai.com/doi/pdf/10.1556/OH.2010.28783

The Antiretroviral Therapy Cohort Collaboration (2010): Causes of Death in HIV-1 Infected Patients Treated with Antiretroviral Therapy 1996-2006: Collaborative Analysis of 13 Cohort Studies. Clinical Infected Diseases, 50, 10, 1387-1396. DOI: 10.1086/652283, https://academic. oup.com/cid/article/50/10/1387/377418

Tóth E. (2018): HPV asszociált fej-nyaki daganatok. Magyarországi epidemiológiai vizsgálat eredményei: Mesopharynx laphám karcinómák HPV pozitivitásának aránya beteganyagunkban. Magyar Dermatológiai Társulat Nagygyülése 2018

Unemo, M. - Shafer, W. M. (2014): Antimicrobial Resistance in Neisseria gonorrhoeae in the $21^{\text {st }}$ Century: Past, Evolution, and Future. Clinical Microbiology Reviews, 27, 3, 587-913. DOI: 10.1128/CMR.00010-14, https://cmr.asm.org/content/27/3/587.long

U.S. Preventive Services Task Force (2019): Final Recommendation Statement: Chlamydia and Gonorrhea: Screening. https://www.uspreventiveservicestaskforce.org/Page/Document/RecommendationStatementFinal/chlamydia-and-gonorrhea-screening

van den Broek, I. V. - Steftsu, O. - van der Sande, M. A. et al. (2016): Changes in Chlamydia Control Activities in Europe between 2007 and 2012: A Cross-national Survey. European Journal of Public Health, 26, 3, 382-388. DOI: 10.1093/eurpub/ckv196, https://www.ncbi.nlm.nih.gov/ pmc/articles/PMC4884327/

Várkonyi V. - Tisza T. - Horváth A. et al. (2000): Epidemiology of Syphilisin Hungary between 1952 and 1996. International Journal of STD \& AIDS, 11, 5, 327-333. DOI: 10.1177/0956462 40001100509, https://www.researchgate.net/publication/312511480_Epidemiology_of_Syphilis_in_Hungary_between_1952_and_1996

WHO (2019): Sexually Transmitted Infections (STIS). https://www.who.int/news-room/fact-sheets/ detail/sexually-transmitted-infections-(stis)

URL: aidsinfo.unaids.org 